\title{
REMEDIES AVAILABLE TO THE GOVERNMENT UNDER THE SHERMAN ACT
}

\author{
WENDELI BERGE*
}

The antitrust laws provide both criminal and civil remedies. Section I of the Sherman Act makes every contract, combination or conspiracy in restraint of trade illegal. It provides that every person who violates the section shall be deemed guilty of a misdemeanor, and subject to fine or imprisonment. Section 2 provides that every person who shall monopolize, or attempt to monopolize, or combine or conspire with other persons to monopolize any part of trade or commerce among the several states shall be guilty of a misdemeanor, likewise punishable by fine or imprisonment. In addition to these criminal provisions, the district courts are given jurisdiction to entertain equity suits to prevent or restrain violations of law through the issuance of injunctions.

The criminal remedy is essentially coercive. It penalizes past illegal conduct. It operates as a deterrent against repetitions of such conduct. The Sherman Act in its present form is fundamentally a criminal statute. The civil remedies are supplemental for the purpose of furnishing additional redress where the facts call for it.

It is the announced policy of the Department of Justice, unless there are compelling reasons to the contrary, to bring criminal actions rather than suits for injunction where the evidence indicates that illegal acts have been committed. In particular situations, there may be extenuating circumstances which warrant the Department in bringing civil suits instead of criminal suits, such as long continued acquiescence on the part of the Government in the commission of the illegal acts. But in general there can be few reasons for failing to present evidence of criminal violation to a grand jury. The Department should not take the responsibility of declining to present evidence in a criminal prosecution where it has that evidence in its possession.

There has been much confusion of thought upon this subject. It seems to be the view of some people that, despite the fact that the statute makes violations misdemeanors, nevertheless the criminal procedure should not often be used. These people, however, do not expect that prosecuting attorneys under other criminal

*A.B., 1925, University of Nebraska; LL.B., 1927, S.J.D., 1930, University of Michigan. Member of the District of Columbia Bar. Special Assistant to the Attorney General of the United States, and first assistant to Assistant Attorney General Thurman Arnold in charge of the Antitrust Division of the United States Department of Justice; alternate member of the Temporary National Economic Committce. Contributor to legal periodicals and author of various speeches and short papers on the enforcement of the antitrust laws. 
statutes shall refuse to carry out the statutory mandate and instead go into a court of equity. Injunctions against the commission of crime are not the accepted procedure that prosecuting attorneys follow in misdemeanor cases.

Now and then legal critics of a vigorous enforcement policy who dislike to see the criminal process used try to draw a distinction as a guide for choice of remedies between acts that are mala in se and those acts which are mala prohibita. That is, they would have us believe that where the criminal laws are directed against such practices as are not condemned traditionally on moral grounds as being wrong in themselves, the criminal remedies should not be pursued, but civil remedies instead should be followed. These critics say that because violations of the antitrust laws may not, according to the moral opinion of mankind, be in a class with embezzlement, arson, or the more heinous offenses, they should therefore not be prosecuted criminally despite the plain wording of the statute that they are criminal offenses.

If a state or county attorney were to refuse to prosecute those felonies or misdemeanors which in his opinion did not involve acts that are mala in se, it would probably not be very long before he would be hauled up for impeachment. Clearly, criminal statutes should not be sidetracked simply because they are not aimed at conduct that is wrong in the traditional moral sense.

The officials charged with the enforcement of the antitrust laws are charged with the enforcement of a criminal statute aimed at acts which the American people for 50 years have regarded as anti-social. The criminal remedies were no doubt provided in the broad sense to coerce obedience to those laws.

The civil remedy, on the other hand, can have a definite, constructive value, looking to rearrangements in the conduct of business to bring it in line with the law. There are situations where long acquiescence on the part of the Government makes the institution of criminal proceedings inequitable. There are other cases where effective public relief can only be accomplished through equity suits. Typical of these latter cases would be a case of a company that had built up a monopoly through the acquisition of many competing units, and where effective public relief might depend upon a systematic decentralization of the economic power of the company by an ordered divestiture of its holdings, under the supervision of a court of equity. The Standard Oil Company ${ }^{1}$ case of Igrr would be typical of this class of cases. Another instance would be the Swift \& Company ${ }^{2}$ case in which the packing interests were required under the supervision of a court of equity to unload some of the allied businesses which they had acquired. These are situations in which a criminal prosecution, at least standing alone, would not afford a full measure of public relief.

An injunction not only may forbid in express terms those acts which violate the law, but it may also forbid many acts which, taken by themselves, do not violate the law. An injunction may forbid many separate acts lawful in themselves, but which operate in practical effect, when taken together with other acts, to defeat the broad

${ }^{2}$ U. S. v. Standard Oil Co. of N. J., 22I U. S. I (1911).

${ }^{2}$ U. S. v. Swift \& Co., 286 U. S. 106 (r932). 
purposes of the antitrust laws. More than this, an injunction may contain positive mandatory provisions requiring definite and specific rearrangements and realignments in an industry, the adoption of new techniques for carrying on business, and the doing of many affirmative acts which in and of themselves the law does not require. In other words, an injunction may contain in all its detail a practical plan for the accomplishment of the purposes of the antitrust laws, and in so doing may contain many provisions which isolated and by themselves seem to go beyond the actual requirements of the law.

This is best illustrated by an example. An injunction requiring a divestiture by one corporation of its stock in another corporation will customarily contain many provisions relating to the manner in which the divestiture shall be accomplished. There are many possible ways of carrying out a divestiture. It might be lawful in a given case to provide for distribution of the stock of the subsidiary corporation to the stockholders of the parent corporation, or to have a public offering, or to appoint a trustee to sell as was done in the Swift case. Any of these alternatives might be lawful; but the court must make a choice and provide expressly and in reasonable detail for carrying it out. The detailed provisions in and cf themselves cannot truly be said to be required by the law, because there are always the other possible legal alternatives for accomplishing the purpose of the law in addition to the method chosen by the court and provided in the decree. But if a decree is to be at all practicable it must contain a specific plan stated in detailed provisions, and an injunction requiring a divestiture in order to be workable must expressly provide a method for accomplishing the desired result. Therefore, it is, true that any scheme provided in the injunction for accomplishing the divestiture must go beyond the actual requirements of the law.

Indeed, an injunction merely stated in general terms would as a practical matter be worthless. The law itself in general terms forbids monopoly and restraints of trade, and an injunction merely reasserting the provisions of the law would add nothing to the law itself. It might be said, therefore, that an injunction is an endeavor to provide a workable and practical plan for effectuating the purpose of the law, and that such method necessarily provides details not expressly required by the law itself.

There is no reason why civil and criminal remedies can not and should not be pursued concurrently. Cases may well arise where effective public relief requires both criminal prosecution and an injunction. The statute expressly authorizes the use of both remedies. The Supreme Court has said in the case of Standard Sanitary Mantlfacturing Company v. United States: ${ }^{3}$

The Sherman Act provides for a criminal proceeding to punish violations and suits in equity to restrain such violations, and the suits may be brought simultaneously or successively. The order of their bringing must depend upon the Government; the dependence of their trials can not be fixed by a hard and fast rule or made imperatively to turn upon the character of the suit. Circumstances may determine and are for the consideration of

${ }^{3} 226$ U. S. 20,52 (1912). 
the Court. An imperative rule that the civil suit must await the trial of the criminal action might result in injustice or take from the statute a great deal of its power.

Thus it is clear as a matter of law that criminal and civil actions may be brought concurrently or successively and that the order in which they are to be brought is for the determination of the prosecuting arm of the Government.

The policy of the Department of Justice in the matter of maintaining criminal and civil suits concurrently was summarized in a public statement issued on May I8, 1938:

I. The Department will not compromise a criminal case upon an agreement by the defendants to refrain in the future from the violations with which they are charged. We cannot accept the responsibility of condoning violations of the antitrust laws because of a promise to reform.

2. The commencement of a grand jury proceeding or a criminal prosecution does not do away with the presumption of innocence which surrounds any defendant. It only means that this Department is i: - ression of evidence of violation of law which it deems so compelling that it cannot accepi .e responsibility of ignoring it and must therefore present it to an impartial judicial tribunal. While the Department must exercise a preliminary judgment as to the weight of the evidence, the ultimate responsibility for the weighing of that evidence is necessarily on the grand jury and petit jury and the court.

3. In using civil and criminal proceedings concurrently, (a practice which has been approved by the Supreme Court in the case of Standard Sanitary Manufacturing Co. v. United States), it is not the purpose of the Department to coerce or compel the prospective defendants to consent to a civil settlement on threat of criminal prosecution. The sole purpose of the criminal proceeding is to present to an impartial tribunal evidence which leads the Department to believe that the antitrust laws have been violated. At the same time it has never been the policy of the Department to bar its doors at any stage of the proceeding against businessmen who may desire to propose a practical solution which is of major and immediate benefit to the industry, to competitors and to the public and which goes beyond any results which may be expected in a criminal proceeding.

Such a solution must be voluntary. While we do not invite the submission of such proposals, it will be our policy in all cases to examine and consider any which may be made. They must offer in addition to a prohibition of the violations of the antitrust laws with which the prospective defendants are charged, substantial public benefits connected with the policy of maintaining free competition in an orderly market which could not be obtained by the criminal prosecution.

If proposals of this character are submitted to the Department, it conceives that its duty is to present them to the court before whom the proceeding is pending in order that he may determine whether a nolle prosse is justified in the public interest.

What has already been said above about equity proceedings applies to an injunction in a contested proceeding as well as to an injunction entered by consent. It is true, however, that through a consent decree there is even greater latitude for the accomplishment of results outside the technical requirements of the law than through a contested proceeding. Thus, a consent decree may contain various socially desirable provisions for reforming the conduct of an industry even though the Government could not force the defendants to accept such provisions. ${ }^{4}$

'An example of the use of consent decrees to settle antitrust litigation is found in the prosecution of the major automobile companies and their associated finance companies, a proceeding begun in 1937. 
A consent decree must, of course, originate. with the defendants as an offer of settlement of the litigation. The Government cannot force the acceptance of any provision in a consent decree and there are often very definite limitations on the Government's right to suggest provisions in consent decrees, especially when criminal proceedings are pending concurrently.

In the negotiations for consent decrees there is much greater latitude for suggestion and compromise by the Government where a civil suit only has been instituted than where a criminal suit is also pending. Where a civil suit only is pending, the Government may exercise sound discretion in making concessions in return for that which it deems to be substantial public benefit. In such circumstances, if the Government believes that it is in the public interest to accept a decree which the defendants have tendered, and the decree grants substantial relief, although perhaps not all of the relief, sought by the Government in its equity suit, it is quite within the bounds of propriety for the Government to accept such a decree. The Government may feel that its case is vulnerable in certain respects and that the decree which the defendants have submitted gives substantially all the relief that can be hoped for. The Government, therefore, may feel that acceptance of a proposed decree is warranted, even though there is a theoretical chance that more relief could be secured by going through a trial. Where a civil suit only is pending, negotiations may be freely conducted at any stage of the litigation and there is no apparent reason why the Government cannot suggest provisions which might be appropriate for inclusion by the defendants in the decree they submit.

But where a criminal proceeding is pending, the Government's right to urge the inclusion of any particular provisions in a decree offered for settlement of a concurrent civil suit is definitely limited. The criminal proceeding cannot be used to coerce any kind of consent decree. Nor can the Government, when a criminal case is pending concurrently, make compromises or engage in bargaining in order to induce the inclusion of certain decree provisions in return for the concession of others. If, however, parties who have been indicted are willing to offer constructive proposals which are in the public interest and which go beyond what the law requires and beyond anything that might be achieved through successful criminal prosecution, the Department can always receive and consider such proposals and if it deems them

After indictments had been returned by a grand jury at South Bend, Indiana, against the major automobile companies and their associated finance companies and certain individuals, the Ford and Chrysler groups of defendants sought a consent decree from the Department. After some months of consideration a decree was proposed by the defendants which went a good deal further in promoting the public interest than the Department thought could ever be obtained through pressing the criminal proceeding alone. The proposed decree met all the objections of the Department to the manner in which the automobile finance business was being dominated by the major companies, and in addition it contained a code of fair competition which promoted orderly marketing in the industry. The code went further than the law required and its adoption certainly could not have been forced by the Department in any kind of contested litigation. Accordingly, the Department felt justified in recommending that the indictment be nolle prossed after the consent decree had been entered in a suit which was instituted on the equity side of the court.

The General Motors defendants did not submit any decree. The criminal prosecution against them proceeded and, in November 1939, the jury found the corporate defendants guilty and the maximum sentence was imposed. 
in the public interest can submit them to the court for consideration as a basis for settlement of the controversy. If decrees which have been thus voluntarily proposed by the defendants are accepted by the Department, they may be submitted to the court with the recommendation that the indictment be nolle prossed. The vital question in such a situation is whether the proposed decree goes so far in promoting the public interest that the Department is warranted in recommending dismissal of the criminal proceedings.

Although the Department can indicate the general policies which guide it in the acceptance of consent decrees, it is up to the defendants, when criminal proceedings are pending, to present the plan that is to form the basis for settlement. The Department may reject proffered decrees because it does not believe that they eliminate objectionable practices, or because it does not deem them to be in the public interest. The defendants may submit new proposals. However, at no time when a criminal proceeding is pending will the Department of Justice urge any particular provisions for a consent decree. These provisions must be proposed by the defendants.

Moreover, when criminal proceedings are pending, the Department will always reject consent decrees which merely eliminate unlawful conduct. It is not enough when parties have been indicted that they shall promise never to break the law again. Officers charged with the enforcement of criminal laws cannot dismiss proceedings upon the simple promise of the parties to be good. The only consent decrees which the Department is willing to consider during the pendency of a criminal case are those containing provisions for affirmative public benefits which could not be secured by the criminal proceeding alone. The final acceptance, of course, is up to the court.

The public is the client of the Department of Justice in antitrust actions, and not the complainants in the particular cases. The public interest may or may not best be served by pressing all the claims of the complainants, and only the Department has the duty and responsibility of deciding about the institution of proceedings, what the charges shall be, whether a criminal or a civil proceeding shall be instituted, and after filing, how it shall be prosecuted and disposed of in order best to represent the public, who necessarily cannot be called into consultation for advice or instructions.

In determining what is in the public interest, the Department must function according to its best informed judgment. No reasonable man would have the temerity to believe that he is always right, and of course the Department does not assert any such omniscience. But just as any lawyer must exercise his best judgment as to what is in his client's interest, so the Department, in the handling of antitrust suits, must use its best judgment as to what is in the interest of its client, the public.

Thus, the Department has the duty to enforce the law vigorously but responsibly. If the Department repeatedly fails to institute legal actions required by the public interest, the pressure of public opinion will in time assert itself and a more vigorous enforcement of the law will be demanded. Where suits are improvidently brought, the litigants, of course, have full opportunity to assert their rights in court. An 
administration of the law which repeatedly abused its discretion through the institution of unwarranted legal proceedings would also sooner or later encounter the pressure of critical public opinion.

But, inevitably, the prosecution arm of the Government must initially determine whether particular remedies are or are not required, and must also determine whether or not proposed settlements of pending litigation should be approved. These are functions inherent in the prosecutor's office. The Department of Justice must constantly seek to maintain that delicate balance required between the interests of particular complainants and the interests of the general public. Antitrust suits generally involve economic contests between different groups in the business world; contests, however, in which the general public has a large stake.

Whether the Department proceeds by criminal or civil action in particular cases and whether it accepts settlement offers or proceeds to final judgment, its policies are subject to severe scrutiny and criticism from one group or other of the business community at practically every step of the way. This scrutiny and criticism inevitably accompany the responsibility which lawyers charged with the enforcement of the antitrust laws must expect, and cannot avoid. It is hoped that the present activity of the Department of Justice will focus public attention on such weaknesses as exist in present procedures and that the way will be pointed toward wise procedural improvements.

Specific procedural improvement has already been proposed in the O'Mahoney Bill ${ }^{5}$ providing additional civil remedies against violations of the antitrust laws, which bill is now pending in the Senate. A similar bill ${ }^{6}$ introduced by Representative Hobbs is pending in the House of Representatives.

The O'Mahoney Bill provides that any violation of any provision of the antitrust laws by any company shall be deemed a violation by each officer or director who shall have authorized any act constituting the violation in whole or in part. In any proceeding against any officer or director he shall be presumed to have authorized company action if he shall have had knowledge of any act constituting part of the violation. If evidence is introduced in behalf of such officer or director to rebut such presumption, the fact of his knowledge shall nevertheless be submitted to the jury, or if the case is tried by a court without a jury it shall be taken into account by the court as evidence of such authorization. The bill provides that officers or directors who have authorized the acts constituting antitrust violation shall be liable for civil penalties to be measured by reference to their compensation and recovered in a civil action brought by the United States. The bill also provides that in a civil suit by the United States such officers or directors may be enjoined from rendering any service to their company, permanently or for a specific period not less than ninety days, and from receiving any compensation during such period. The companies also may be enjoined from receiving service from such officers and directors during such period and from paying any compensation to them while the ban is in effect. The bill also provides a direct company financial liability to be recovered in a civil suit

\footnotetext{
'S. 2719, 76th Cong., Ist Sess. (1939).

${ }^{8}$ H. R. 7035, 76th Cong., ist Sess. (1939).
} 
brought by the United States. In effect the bill treats violations as public torts rather than crimes.

Although there may be some reasonable question as to whether the precise penalties provided in the O'Mahoney Bill in its present form ought to stand finally or whether the bill might appropriately be amended in certain particulars, nevertheless it is believed that the bill represents an important step toward strengthening antitrust enforcement. It is believed that the principle of direct civil liability of officers and directors for the acts they authorize should be adopted in the antitrust laws.

The criminal responsibility of officers and directors for corporate action which they authorize is clear under present law. Courts and juries, however, have been loath to enforce it. Effective antitrust enforcement cannot be had if penalties are to run only against the fictitious corporate person. There undoubtedly would be less reluctance on the part of courts and juries to apply civil penalties against those individuals responsible for the lawless conduct of the corporations they direct, than is present in criminal proceedings.

Moreover, the O'Mahoney Bill provides a technique for enforcement without invoking all of the emotional. disturbance which generally attends the use of the criminal process. While civil penalties may be as severe in their financial effect as criminal penalties, yet they do not involve the stigma that attends indictment and conviction. Most of the defendants in antitrust cases are not criminals in the usual sense. There is no inherent reason why antitrust enforcement requires branding them as such. If there were some real hazard, other than criminal prosecution, perhaps effective enforcement could be secured without criminal prosecution. But if effective civil penalties are absent, there is no real hazard. Under the present law businessmen know that an injunction amounts to nothing more than a specification of what activities will be regarded in the future as violations of law. Stated otherwise, the injunction simply enumerates practices that already are illegal, and in effect advises the defendants that they will have another chance to comply with the law before encountering any serious risk. Until an injunction is issued parties operate under no real deterrent. It is time enough to comply with the law after they are enjoined.

If the O'Mahoney Bill is enacted, there will be added to the law a deterrent which ought to be effective and which does not require indictment and the other consequences of criminal prosecution so unpopular with the business community. But until the O'Mahoney Bill, or some measure incorporating similar principles, is enacted there can be no let-up in the use of the only real enforcement weapons now at hand. As the law now stands effective enforcement means criminal enforcement. If the continued vigorous application of present remedies should sooner or later convince the business community that the enactment of the principles of the O'Mahoney Bill would provide a fairer procedure for enforcement, then it is believed that the enforcement agency could appropriately employ the new civil penalties in all but the most flagrant cases. 